\title{
Incommunicado detention and torture in Spain, Part III: 'Five days is enough': the concept of torturing environments $i$
}

\author{
Pau Pérez-Sales, MD, PhD*, Miguel Angel Navarro-Lashayas, PhD**, Angeles Plaza***, \\ Benito Morentin, MD, PhD****, Oihana Barrios Salinas*****
}

\begin{abstract}
Background: Torture is changing in western societies, evolving from pain-producing torture to more subtle mixed psychological methods that are harder to detect. Despite this, there is not an adequate understanding of the complexities of contemporary psychological techniques used in coercive interrogation and torture. Methods: The interrogation and torture techniques used on 45 detainees held in short-term incommunicado detention in Spain during the period 1980-2012 were analyzed. The list of torture categories set out in the Istanbul Protocol (IP) were assessed quantitatively. Software-aided qualitative analysis of the testimonies was conducted, using both inferential and deductive approaches to deduce a classification of torture techniques from the point of view of the survivor. Findings: The most frequent
\end{abstract}

\footnotetext{
*) SiR[a] Centre, GAC Community Action Group and Hospital La Paz, Spain.

$\left.{ }^{\star \star}\right)$ Human Rights Section, Spanish Association of Neuropsychiatry (AEN).

${ }^{\star \star \star}$ ) GAC - Community Action Group, Resource Centre on Mental Health and Human Rights, Spain.

$\star \star \star \star \star)$ ARGITUZ - Human Rights Association and

Section of Forensic Pathology, Basque Institute of Legal Medicine, Spain.

$\star \star \star \star \star \star)$ Jaiki-Hadi Prevention and Assistance Association.
}

Correspondance to: pauperez@arrakis.es

${ }^{i}$ Editor: Lilla Hárdi. methods according to the IP categories used against detainees were isolation and manipulation of environment (100\%), humiliation (93\%), psychological techniques to break down the individual (91\%), threats $(89 \%)$ and forced positions and physical exercises until extenuation (80\%). Additionally, with a frequency of between 51 and $70 \%$, mild but constant blows, being forced to witness the torture of others, hooding (mainly dry asphyxia) and unacceptable undue conditions of detention were also frequent. Sexual torture was also widespread with sexual violence (42\%), forced nudity (38\%) and rape $(7 \%)$. Qualitative analysis showed that most detainees were submitted to coercive interrogation using a wide array of deceptive techniques. This is often a central part of the torturing process, frequently used in conjunction with many other methods. It was found that giving false or misleading information or making false accusations was most frequently used, followed by maximization of responsibility or facts and giving false information regarding relatives or friends. Different patterns of harsh interrogation, ill-treatment and torture are described that appear to have been tailored to the profile of Basque detainees. Interpretation: The study shows the need to improve the conceptualization of psychological torture suggested by the IP. Key to this view is the idea that we must not concern ourselves with 'torture methods' but 
with Torturing Environments. The concept of Torturing Environments is defined and proposed as a focus for future study.

Keywords: Torture, torturing environments, incommunicado detention, psychological torture, interrogation procedures, deception, Istanbul Protocol.

\section{Introduction}

Historically, torture has been wrongly associated with the production of physical pain. ${ }^{1,2}$ Pain is certainly part of an overall process of breaking down the mental state of the person who is being tortured. ${ }^{3}$ However, contemporary torture, particularly in western societies, is changing in that psychological torture which does not leave marks is increasingly replacing pain-based torture. As torture is generally accepted to be a process of compliance and submission, humiliation and psychological breakdown, psychological torture can be more targeted and efficient, often achieving the desired effect in a shorter time (see statements 1 and 2, Appendix A). ${ }^{4-5}$

In Spain, anti-terrorist laws allow for incommunicado detention for up to five days, which can be extended to 13 days, during which the right to communicate with family members and have access to lawyers or doctors of the detainee's choice is denied. ${ }^{6}$ Incommunicado detention has been repeatedly denounced as contrary to international law by different human rights bodies and was even considered as amounting to torture by the United Nations Special Rapporteur on torture and other cruel, inhuman or degrading treatment or punishment. ${ }^{7-12}$

The Spanish police are trained in the use of the Reid technique, a harsh method of questioning subjects by means of a progressively accusatory process. ${ }^{13}$ Unlike cognitive interviewing, where the interrogator tries to build a positive atmosphere of dialogue and cooperation with the detainee, ${ }^{14}$ it assumes that the detainee is guilty. The investigator uses an escalation of coercive procedures and deceptive tactics with the aim of self-incrimination. Unsurprisingly, the technique has been reported to produce very high rates of false confessions. ${ }^{15,16}$

There are very few contemporary systematic studies on ill-treatment methods in Europe. Studies on incommunicado detention in Spain have been mostly descriptive, only consisted of testimonial reports or provided rough estimates of the frequency of mainly physical torture methods. They offer scant information about the dynamics of modern psychological torture and its consequences. Even the IP arguably lacks detailed guidelines on how to explore and report on psychological torture. ${ }^{5}$ It is therefore a priority for future research to recognise and focus on how psychological ill-treatment and torture is now being conducted.

The objective of this paper is to describe the ill-treatment and torture techniques used by the Spanish security forces on incommunicado detainees, including the coercive interrogation techniques which make up a torturing environment, as well as providing some methodological reflections on the epidemiology of torture methods for similar studies in the future. The concept of Torturing Environments is presented, a term which allows a more meaningful understanding of the dynamics of interrogation procedures and of the psychopathological consequences of current ill-treatment and torture.

\section{Method}

A stratified purposive sample of Basque people $(\mathrm{N}=45)$ held under incommunicado detention between 1980 and 2012 in Spain 
who have reported ill-treatment or torture during detention was selected. The participants and the methodology of assessment have been described in Part II. Data were obtained through extensive clinical interviews following a semi-structured script based on the IP conducted by psychiatrists or clinical psychologists. Forensic experts collected, as part of the IP, a detailed account of the conditions of detention and interrogation, and allegations of ill-treatment. These interviews were recorded on video or audio (as chosen by the interviewees) and transcribed.

\section{Analysis of data}

\section{Quantitative analysis}

Torture techniques according to categories set out in the IP were coded. In order to evaluate if torture methods have changed during the last decade, two periods: 1980 to 2002 and 2003 to 2012 were compared. Chi-square tests were used to assess differences in the distribution of torture methods for those with a frequency $>10 \%$ in the two periods. Level of significance was set up at $p$ $<0.05$. All the analyses were performed using the Statistical Package for Social Sciences (SPSS 17.0)).

\section{Qualitative analysis}

All 45 IP descriptions of sessions were submitted to content analysis using Atlas. ti.6.0 software for text analysis. Two methodologies were used:

(a) Inferential methodology. Through the Atlas.ti analysis, a thesaurus of all the terms related to torture methods that appeared in the statements was obtained.

(b) Deductive methodology. Additional codes were generated through an in-depth reading of the 45 testimonies according to theoretical models of conceptualization of torture methods.
The results of (a) and (b) were collated and grouped into conceptual nodes. Nodes were latter interconnected into conceptual families. A final report was produced with the hierarchy of nodes and families and all the quotations for the IP that supported each of them. These data were analysed over a time line in order to elaborate a prototypical process of detention and ill-treatment which helped to understand the dynamics of an interrogation procedure.

\section{Results}

Quantitative analysis: Methods of physical and psychological torture

Table 1 shows the frequency of torture techniques. Torture exposure is cumulative and the results show that the detainee is submitted to a large number of physical and psychological methods simultaneously or successively. Most of the survivors reported isolation and manipulation of environment (100\%), humiliation (93\%), psychological techniques to break down the individual (91\%), threats (89\%) and positional torture (forced positions and physical exercises) (80\%). These could therefore be considered the core torture techniques used in incommunicado detention in Spain. Also widely used, are blows (mild but constant) (69\%), forcing the victim to witness torture $(67 \%)$, hooding (with dry asphyxia on most occasions) (47\%), and unacceptable conditions of detention (56\%). Sexual torture was also common with reports of sexual violence $(42 \%)$, forced nudity (38\%), and even rape $(7 \%)$.

In relation to the distribution of the frequencies of torture methods by period of detention (Figure 1), there were not statistically significant differences, except for the electric shocks (most frequently used in the first period), showing that the methods are mainly psychological and remain substantially unchanged. 
Table 1: Frequency of torture techniques according to IP classification $(N=45)$

\begin{tabular}{ll}
\hline & $\mathbf{n}(\%)$ \\
\hline Blunt trauma, beatings. & $31(69)$ \\
Positional torture & $36(80)$ \\
Electric shocks and mock electric shocks & $7(16)$ \\
Asphyxiation, such as wet (water) and dry (hood, bag) methods & $21(47)$ \\
Crush injuries & $2(4)$ \\
Forced nudity & $17(38)$ \\
Sexual violence & $19(42)$ \\
Rape & $3(7)$ \\
Conditions of detention & $25(56)$ \\
Isolation. Alteration of normal sensory stimulation; sleep, food, water & $45(100)$ \\
Deprivation of an adequate medical care & $18(40)$ \\
Humiliation, such as verbal abuse, performance of humiliating acts & $42(93)$ \\
Threats of death, harm to family, further torture, imprisonment & $40(89)$ \\
Mock executions & $6(13)$ \\
Psychological techniques to break down the individual, including forced betrayals, & $41(91)$ \\
ambiguous situations etc & \\
Forced betrayal of someone placing them at risk of harm & $12(27)$ \\
Forcing the victim to witness torture or atrocities being inflicted on others, or records of \\
screaming, music, etc.
\end{tabular}

Figure 1. Methods of torture in relation to period of detention: Types of torture (\%) from 1980 to 2002 (black columns, $n=21$ ) and 2003 to 2012 (grey columns, $n=24$ )

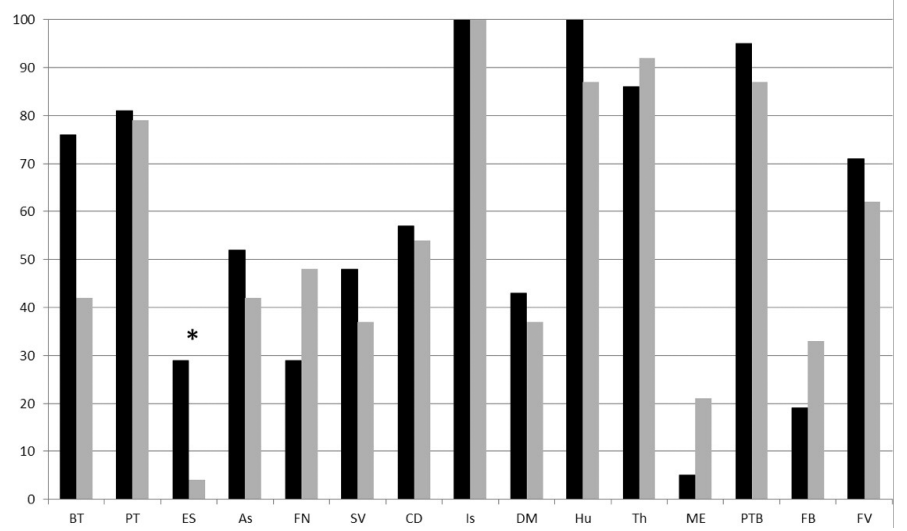

$\mathrm{BT}=$ Blunt trauma; $\mathrm{PT}=$ Positional torture ES = Electric shocks; As = Asphyxiation $; \mathrm{FN}=$ Forced nudity SV = Sexual violence $\mathrm{CD}=$ Conditions of detention; $\mathrm{Is}=$ Isolation; $\mathrm{DM}=$ Deprivation of medical care; $\mathrm{Hu}=$ Humiliation; Th $=$ Threats ME = Mock executions; PTB = Psychological techniques to break down the individual $\mathrm{FB}=$ Forced betrayal $; \mathrm{FV}=$ Forcing the victim to witness others torture. ${ }^{\star} \mathrm{p}<0,05$. 


\section{Qualitative analysis: Conceptual nodes and families}

Tables 2 and 3 show the conceptual nodes and families including representative quotations as a way of description. A more detailed account of each one can be found in the final report. ${ }^{17}$ Coercive interrogation techniques (Table 3) are part of contemporary torture. The core technique in coercive interrogation is deception, defined as the purposive use of misleading threats and questions to obtain information from a detainee. ${ }^{18}$ Table 4 summarizes the frequency of deceptive mechanisms used in incommunicado detention in Spain. Two out of every three detainees reported maximization of facts, responsibility or consequences, false information about their family being detained or in immediate danger, false accusations (false witnesses or false indictments) or making false promises of leniency.

\section{Cumulative effect}

The classification in categories does not reflect the fact that techniques were applied simultaneously and that the combined effect is what produces a strong impact in a very short time. Five days was enough to produce a state of confusion and disorientation in which deceptive questions had a major influence (see Appendix A).

\section{Dynamics of interrogation}

A prototypical process of detention and ill-treatment in incommunicado detention appeared as follows:

(1) Initiation. Two patterns emerged:

a. Flooding. The detention is very violent from the outset, using an explosion of ferocity that begins from the very moment of detention or transfer, and cannot be stopped by the detainee whatever he or she does. When the true interrogation starts, the detainee is terrorized. The interrogators often make serious charges involving links to terrorist activities that involve long sentences right from the beginning. The charges are presented as fact and only the 'correct' answers are allowed. False evidence is shown and confirmation, further details and a signature on a written confession is expected.

b. In-crescendo. No formal charges are brought at any moment and the detainee does not know the cause of detention. The person is then submitted to open exploratory questions in a soft tone. The aggressiveness of the interrogation increases if the detainee does not progress in the desired direction by the use of verbal assaults coupled with mild but constant physical violence. This usually culminates in humiliations and threats at the end of the second day or beginning of the third.

(2) Intermediate sessions: The progression of the interrogations changes over time and depending on the detention center. The most frequently used involves the alternative use of long and exhausting interrogations for up to 12 hours (by teams who take turns), combined with periods of isolation that foster anxiety, rumination, fear, disorientation and confusion. In a standard session:

- The space is small, the person is partially or fully naked, usually deprived of vision and there are several interrogators acting in a coordinated manner.

- Physical torture (anoxia, repeated and rhythmic beatings, deprivation of food and sleep) are combined with use of deceptive information, humiliation and 
Table 2. Classification by nodes (torture methods) and families (categories of torture methods according to its purpose): Examples in the words of the detainees

\section{Basic Human Needs (Very Frequent 80\%)}

1. Physical space: cell and detention conditions. "I remember the cell, very dark, with a concrete cot with a blanket that I think had [remains of] blood on it, it was very dirty and it was stiff."

2. Sleeping and waking rhythm disruptions. "I could hardly sleep, most of the time (the first three days) they left the lights on and went and opened the hatch, or knocked on the door to wake me up."

3. Food and liquid intake. "I had very cracked lips because my lips were very dry and after going to the forensic doctor, the Civil Guard official gave me water. Till then they had not allowed me to drink and it looked as if they withheld it in return for information: "If you want to drink water you have to tell us this"."

4. Physical exhaustion - forced positions - strenuous exercise. "I had to do push-ups up and down, I had to stand upright and then squat, I could not stand up, I fell against the wall, I was dizzy, stunned."

Relationship with the environment and sense of orientation [Very Frequent 60\%]

1.Visual manipulation - lighting conditions. "Then the night came. The cell (...) had a light that illuminated it all (...) and a fan on the side, two on the roof. The light stayed on continuously for 4 days, as well as the fan, so there was a constant noise."

2. Auditory manipulation - Noises. "The music was very loud, so that we could not hear the cries, I suppose,, because in the moments they turned off the music I heard the other detainees screaming."

3. Temperature. "It was spring and the day was hot, so I was dressed in a tank top, but at night it was cold. They wet my arms and opened the window to let in the cold, I was shivering. "

4. Time Manipulation. "You don't know what time it is or anything. I've never used a watch and after what happened I now always wear a watch, I just cannot not know what time it is now. Before, I did not care "I can always ask » (...) The timing issue is amazing, finally you got disoriented and you don't know if things take an hour or a day. I had only spent a day and a half and I thought «I must be on the fourth day or so. »".

\section{Need for safety [Very Frequent 80\%]}

1. Fear of the unknown- Uncertainty. "The worst was fear. (...) It's so surreal that you do not know what to think... what is this? Nobody will believe this. My friends are from the nationalist left and know that torture exists, but you cannot imagine that situation, every minute, for five days. It's surreal."

2. Waiting for pain. "Imagine how I must have been as I told them, crying, shock me now, shock me now. (...) That situation was ... I don't know, you can stand physical harm, but before suffering such harm it is the fear, the anticipation of whether he is going to hit me or not? (...) They also realized this, they saw how I was shaking, crying, screaming, I don't know."

\section{Psychological perception of death - asphyxiation [Frequent 40\%]}

1. Dry asphyxia (use of bags, hoods and other methods of suffocation). "The use of la bolsa is continuous. First, they pull the bag on you without tightening and they go on questioning you while hitting you, and then they begin to tighten and squeeze until you get to the asphyxiation point. One, two, ten, twenty, thirty, forty times, a hundred times. (...) Then you enter into a fucking stifling situation (...). And it is like this all the time. All of this while they are screaming at you, asking questions."

2. Mock executions. "During the interrogation, a Civil Guard who was standing behind me, started making a noise with a gun, he told me that he was going to shoot me in the head, that he would kill me. $\mathrm{He}$ asked whether I thought he had bullets or not... He put the gun up to my head and fired twice. Both times there was a click. This interrogation was very hard." 


\section{Physical pain}

1. Low intensity rhythmical and constant blows. [Very Frequent $60 \%$ ]

During the interrogation, they spoke to me, they hit me, like a drop of water that keeps on falling, they pounded on you, and pounded on you, until you got a splitting headache. The blows were not really strong, nor were they insignificant, but their cadence BOOM, BOOM, BOOM, all the time."

2. Use of electric shocks and mock use of electric shocks". [Rare 20\%]

"And they began to threaten me also with the electrodes. "We're going to put the electrodes on you." Then, they approached something sizzling to my ear, like something producing sparks. (...). In the end they attached them to me. On the ears, on the penis and testicles. They were not very strong, but I was terrorised, the fear that caused in me was very big."

\section{Psychological integrity - self-concept}

1. Attacks on sexual and gender identity: molestation, abuse and rape. [Frequent 40\%] "They took me to a place and said «Slut, get undressed, take off all your clothes, you bitch! » At first I said that I didn't want to, then they started to force me to, and in the end I took them off. At first I didn't take off my pants but they ordered me to take it all off. And I took them off. I heard laughter. "Ok, it's done, we've already seen you, we have seen what we had to see. Now get dressed! "”

"He passed what I think it was a stick, a rounded thing, between my legs. «I'm getting you hot! » He said, "Here, this bitch is going to come, we're going to make her come. " I thought, "My God how can he say that! " Until he reached the vagina and pushed...

2. Attacks on the self. Attacks on political, social and personal identity. [Very Frequent $60 \%$ ] Dignity and respect: humiliation, shame and sense of personal value: "Just to be held incommunicado is an outrage, going five days knowing nothing of the outside world is an atrocity. You feel like crap, vulnerable; you're the last shit there. You are between fear... above all fear and helplessness, like an ant among people. You feel that it will never end, that you've lost."

"Although 10 years have passed since these facts, [I] remember the insults, "Idiot, stupid, slut, bitch, useless twat, martyr, arrogant whore... ". (...). [I] did not react, and did not respond."

Questioning social identity and militancy: "If I had to describe the hard part, of abuse, rather than the blows that hurt, it is the damage they do to you as a person. They get you to feel like a bug. That you are a normal person and suddenly your feelings are not the same. (...) The blows hurt and leave you marks (...) but the harassment of "I'll kill you, I'll kill you", "I'll rape you" they get you to believe it and say "Well, this is the end, this is as far I've come and I will not stand it any longer. "”

\section{Need for affiliation and sense of belonging [Very Frequent 80\%]}

1. Loneliness - isolation. "But the scariest thing was to go back to the cell, because I had no distraction there. I used to think about things but that... that was hard, I could not rest, all the time thinking about the threats they had made basically against my family. (...) When I went to the cell... going over all that they had told me and I could not get it out of my head, I could not."

2. Threats to family and environment. " "Poor mother" and in the end it was true, the fear of what might happen to her was tremendous, and "what your relatives are going through because of you", "whatever happens to them will be your fault» And that was all for me, the feeling of guilt; it really is true that my relatives were going through bad times."

3. Family environment: emotional manipulation and guilt. "At one point they showed a picture of my sister. When I saw that picture I got emotional and began to cry. Then I remember one of them saying: "Now his legs are shaking and he is half crying. " And then they all came and pulled the bag on me." 
Table 3: Coercive interrogation techniques: Examples in the words of the detainees

Confusion and daze during interrogation. "So, there were times when you said: "I will declare whatever you want and sign whatever you like" and at other times you know that you are in the right and you say: "These guys are going to fuck my life and put me in prison for life by declaring something I don't know nothing about." It was all the time like the angel and devil speaking in my head. There, in that situation, you're not completely aware of things; it is a matter of living the moment, the present, which is coming, and you just want to get out. There were moments when you think: "but is this real or am I dreaming?" It was really surrealistic."

Breaking silence and not allowing negative answers. "I was blocked: I didn't want to talk; (...) besides, this is how they begin: with silly questions, without relevance. You cannot say you do not know the answer. They start with small things and go on playing with that. (...) And then they change their strategy and involve you by asking simple questions you do know the answer to in an ordinary or even pleasant way , to see if you say anything else. (...). But, come on, I thought that I didn't know what kind of information they wanted from me, which I did not have."

Contemplation time. "Everything was perfectly organized, they took you out from the cell quickly, the interrogations were long and when they saw that you were tired or that they had said something that had worried you, they got you into the cell and left you there to worry about it, not allowing you to sleep, with music, and very strong lighting."

Omnipotence and omniscience. "The second interrogation was the one which did the most damage to me; they started telling me my life since I was twelve until the day I was arrested. What they told me was a lot. They knew everything (...) I was left with the feeling that they knew everything that they had seen or had found out before, but they knew it all. And that's when I went downhill. (...) I felt vulnerable, surprised, they knew everything about me."

"«You'll have the rights that we want you to have " they said. That was it, you were in his hands, that was, what they wanted, exactly what they wanted. At the end I signed, I signed what they wanted."

Deception. "There were calls from another group of policemen as if they were talking to those in the reserve. One of them yelled and everyone fell silent. Everyone started to comment on "How crazy, that's too much! " They sat me in a chair and one of them told me that my mother had died."

"I don't know how they made me believe that my sister was a detainee in another room. It seemed true because even the voices sounded like hers. And of people close to me... of people very close to me, it was so believable... because you thought that they were being tortured in the cell in front. People of the family who were detained in another room and they made you believe that this was true."

"At the beginning, or so I was told, I was going to be in prison for a long time; I was going to have a sentence of many years... And suddenly, I was out on bail."

"I remember he started to carry out tests and in all confidence, I told him that I had been beaten and I asked him to look here [pointing to his neck] because I had taken a lot of beating. Suddenly he said: «Boy, you have complicated everything. " "What do you mean? You are not the forensic doctor?... " and he said no, he was a Civil Guard."

Sudden change in interrogation style or interrogator. "It was a tone of voice... like reassuring and then suddenly Bang! She hits you! (...) So, it seems you're fine, and then suddenly you are beaten. I don't know; she would come softly, she would speak softly and then suddenly hit me."

Emotional Manipulation - empathy with alleged victims and guilt. "In a moralistic tone, they told me about their families, about my family. Other times they wanted to talk about politics or about themselves, about how we called them, about what we do, about the Basque police... When they wanted to talk about these issues, they employed a more relaxed voice, did not scream and even laughed at what I said. After this interrogation I was defeated. I could not stop crying, I even yelled ...”

"Psychologically they also crush you. Yes, with the family, also with my mother, they made me feel guilty... my mother had committed suicide: they made me feel guilty about that. 
Forced betrayal and prisoner's dilemma. "They told me that they needed names, because they do not believe that I really didn't know, and come on ... And then they put the bag over your head until you suffocate, and you give them a name. And then again and again... And you end up telling them about so and so's friend whose name I knew, and I was aware I was placing him in a tight spot, because I don't even know whether he is a militant or not. Just to tell them something I'm giving them names of people I don't know... And that makes you feel guilty.”

"They showed me some pictures (...). They were my best friends, my brothers, and they already knew who they were. (...) they were particularly interested in the incrimination of two of them, and later the two were arrested. One was arrested on the same day as I was, and obviously, the day they arrested the second one my world fell to pieces."

"It was not to self-incriminate you but to incriminate. But then one came and told you that your colleague had already compromised you, that he had already signed it was you... and this was continuous."

Absurd orders - submission. "They began to say that I had to do a handwriting test, I didn't know if it was part of the statement, so we did the calligraphic test. I was scared while I did it because I was writing a text which I didn't know if it was absurd or if it was going to be used against me...

Table 4: Deception techniques: Types and frequency.

\begin{tabular}{|c|c|c|}
\hline Deception techniques & Types & Frequency \\
\hline $\begin{array}{l}\text { Providing false or mis- } \\
\text { leading information to } \\
\text { the detainee on a hypo- } \\
\text { thetical charge or con- } \\
\text { viction }\end{array}$ & $\begin{array}{l}\text { - False accusations for which there is no evidence. } \\
\text { - Suggesting false evidence. } \\
\text { - Revealing false witnesses. } \\
\text { - Alleged indictments made by others. } \\
\text { - Threats with convictions on charges involving twenty or more } \\
\text { years in prison. }\end{array}$ & $\begin{array}{l}\text { Very frequent } \\
\text { (around } 60 \% \text { ) }\end{array}$ \\
\hline $\begin{array}{l}\text { Maximization } \\
\text { - Of facts } \\
\text { - Of responsibility } \\
\text { for the crime } \\
\text { - Of consequences }\end{array}$ & $\begin{array}{l}\text { - To exaggerate the importance of the matter under investiga- } \\
\text { tion or its consequences, making false extremely serious } \\
\text { accusations to instigate self-incrimination of a comparatively } \\
\text { lesser crime. }\end{array}$ & $\begin{array}{l}\text { Frequent } \\
\text { (around 40\%) }\end{array}$ \\
\hline $\begin{array}{l}\text { Providing false } \\
\text { information about the } \\
\text { situation in which the } \\
\text { detainee's family is in }\end{array}$ & $\begin{array}{l}\text { - Existence of first-degree relatives detained and / } \\
\text { or interrogated. } \\
\text { - Existence of family members (especially couples) tortured in } \\
\text { nearby cells (shouts, etc.). } \\
\text { - Family suicides. } \\
\text { - Known or close people detained and interrogated. }\end{array}$ & $\begin{array}{l}\text { Frequent } \\
\text { (around } 40 \% \text { ) }\end{array}$ \\
\hline Making false promises & $\begin{array}{l}\text { - Impact of detention on family. } \\
\text { - Promise to call relatives. } \\
\text { - Promise of freedom without charges or with minor charges. }\end{array}$ & $\begin{array}{l}\text { Frequent } \\
\text { (around 20\%) }\end{array}$ \\
\hline Simulations / Staging & $\begin{array}{l}\text { - Recordings or screams of other alleged detainees. } \\
\text { - Noises/Sounds of alleged torture to detainees in } \\
\text { adjoining rooms. } \\
\text { - Police posing as false allies. } \\
\text { - Police posing as torture victims. }\end{array}$ & $\begin{array}{l}\text { Rare } \\
\text { (around 10\%) }\end{array}$ \\
\hline
\end{tabular}


harassment of a sexual nature, emotional manipulation and guilt related to relatives and friends. There is a tailored selection, refinement and progression in the methods used, depending on the perception of the person leading the team of interrogators based on what has the most profound impact on the psychological integrity of the detainee.

(3) Confessions, incrimination and selfincrimination: The interrogations continue until interrogators believe it is possible to make a written statement which must be memorized and repeated word by word before a judge. This is reported to happen between the third and fifth day. If the results are not suitable, the incommunicado detention can be prolonged up to thirteen days.

(4) Closing post-statement: Several detainees reported a final interview after being presented to the judge, using a friendly tone, indicating that everything is now over and that there was no choice and providing comfort, contact or collaboration.

Four out of every five detainees were later transferred to prison, which was reported by most of them as a liberation. This helps to understand the harsh conditions that detainees must endure during incommunicado detention.

\section{Discussion}

This study documented allegations of ill-treatment or torture in 45 persons who have been held in short-term incommunicado detention in the period 1980-2012 in Spain. A comprehensive list of techniques according to the IP categories was obtained and ordered by frequency. The results are consistent with data published in previous studies and reports of international bodies showing that detainees are submitted to a large number of physical and psychological methods simultaneously or successively, and that there is a pre-eminence of psychological torture in breaking the detainee. ${ }^{6-12,19-25}$

Most police handbooks on interrogation around the world use adaptations of the Reid Manual, written in the USA in the 1960's and rewritten and reedited every ten years since then. Interrogation following the Reid technique uses confusion and daze; continuous questioning; not allowing negative answers or breaking the silence; alternating long hours of interrogation with time when the person is left completely alone; calculated use of deceptive techniques; use of omnipotence and omniscience from the interrogator; sudden changes in interrogational style, either by the same interrogator or by two; emotional management of the detainee, playing with feelings of empathy, guilt or shame; use of personal information; forced betrayal, and having to follow absurd and repetitive orders. ${ }^{13}$ The interrogator asks loaded questions, uses false choices, or shows unproven or manipulated data in a graded process that erodes and manipulates the narrative of the detainee until information or a confession is obtained. Its use has been associated with a high number of false self-incriminations. ${ }^{15-16}$ Coercive interrogation techniques are illegal and are considered grounds for a conviction to be overturned in the UK or in Germany, ${ }^{26}$ for example, but are still legal and considered valid investigative practice in countries like the United States, Russia and Spain. ${ }^{27}$ There are clearly strong commonalities between the methods described here and those described in CIA-led programs practiced by the US government ${ }^{28}$ and other examples of contemporary torture, ${ }^{29}$ suggesting shared 
learning and models between western governments.

The present study is limited by the small sample size. It nevertheless suggests that there have not been significant changes in relation to the main methods of torture over time, except for electric shocks which are no longer used (Figure 1). In Tables 2 and 4, the approximations of frequency for each node and family were provided. Exact figures were specifically not provided (as we do for IP categories in Table 1) as this would be misleading; working with qualitative software includes deciding between categories which are not always clear-cut. The frequencies in Tables 2 and 4 are likely to be underestimated because they come from counting quotations derived from Atlas-ti (inferential method). This method allows latent data to emerge and highly increases the reliability of the estimates, but it only offers data on the spontaneous recall of interrogation techniques and thus provides conservative figures.

A Torturing Environment is a milieu that creates the conditions for torture. It is made up of a group of contextual elements, conditions and practices that obliterate the will and control of the victim, compromising the self. ${ }^{5}$ The creation of a Torturing Environment requires the interaction of several elements: (a) sensorial and temporal disorientation and confusion of the selfreflecting mind; (b) fear and terror that starts from the outset of detention and remains present throughout; (c) humiliations and attacks on identity that contribute to eroding any sense of control; and, (d) tension and beatings that produce physical and emotional exhaustion. The capacity of the victim for proper understanding, retrieval of memories, judgement and reasoning is progressively undermined. The techniques of emotional manipulation and cognitive distortion used during the interrogation complete the process. The long term effects on the mind can be devastating, as reflected in Part IV.

Despite the fact that torture does not have to involve physical pain, psychological torture is often poorly explored and not given the attention it deserves in legal claims and by politicians.

Qualitative approaches, such as the one here, can improve the understanding of the mechanisms of contemporary interrogative techniques and their psychological impact on detainees. Whilst the IP does not purport to provide an exhaustive list of torture methods, we believe that some reformulation is necessary; the increasing variety and complexity of psychological techniques need to be more accurately reflected, and we would therefore commend the use of the concept of Torturing Environments with respect to future research in the area. 


\section{References}

1. Scarry E. The body in pain: The making and unmaking of the world. Oxford University Press; 1985

2. Rejali D. Torture and democracy. Princeton University Press; 2009.

3. Viñar M. Ulriksen M. Fracturas de la memoria. Crónicas de una memoria por venir. [Memory fractures. Chronicles of a memory to com]. Montevideo: Trilce; 1990.

4. Ojeda AE. What is psychological torture? In: AE Ojeda (ed). The trauma of psychological torture (pp 1-22). London: Praeger; 2008.

5. Pérez-Sales P. A new outlook for defining and measuring torturing environments. In: PérezSales P. Psychological torture. Definition, evaluation and measurement. London-New York; Routledge; 2016. pp 284-5.

6. Human Rights Watch. Setting an Example? Counterterrorism Measures in Spain, Vol. 17 num. 1 (D), 2005 January. Available from: http://www.hrw.org/sites/default/files/ reports/ spain0105sp.pdf.

7. Amnesty International. Spain: adding insult to injury. The effective impunity of police officer's in cases of torture and ill-treatment. Madrid; 2007.

8. De la Cuesta JL, Muñagorri I, editors. Application of terrorism regulations. Basque Institute of Criminology. University of Basque Country: Donostia; 2009.

9. European Committee for the Prevention of Torture (CPT). Special recommendations after the visit of May 30 to June 13, 2011. Available from: http://www.cpt.coe.int/documents/esp/2013-06inf-esp.pdf.

10. Rodley NS. The treatment of Prisoners under International Law. 3rd ed. Oxford University Press; 2009. p 460ss.

11. United Nations Economic and Social Council. Report of the Special Rapporteur on the question of torture. Civil and political rights, including the question of torture and detentions. Visit to Spain. E/CN.4/2004/56/add.2, 2004. Available from: http://www.unhchr.ch/Huridocda/Huridoca.nsf/(Symbol)/E.CN.4.2004.56. Add.2.En?Opendocument.

12. United Nations Human Rights Committee. María Cruz Achabal Puertas v. Spain, Communication No. 1945/2010, U.N. Doc. CCPR/ C/107/D/1945/2010 (2013).

13. Reid J, Buckley J. Criminal interrogation and confessions. Jones \& Bartlett Publishers; 2011.

14. Gudjonsson GH. The psychology of interrogations and confessions: A handbook. John Wiley \& Sons; 2003.
15. Kassin SM, Drizin SA, Grisso T, Gudjonsson GH, Leo RA, Redlich AD. Police-induced confessions. Law Hum Behav. 2010;34:3-38.

16. Pearse J, Gudjonsson GH. The Identification and Measurement of "Oppressive" Police Interviewing Tactics in Britain. In: Gudjonsson GH, editor. The Psychology of Interrogations and Confessions. A handbook. Wiley and Sons; 2003.

17. Argituz, AEN, Ekimen Elkartea, GAC, JaikiHadi, OME, OSALDE, Departamento de Psicología Social (UPV/EHU). Incommunicado detention and torture. Assessments using the Istanbul protocol. Ekimen Ed. and Irredentos Libros. Bilbao. 2014.

18. Kassin SM, Perillo JT, Appleby SC, Kukucka J. Confessions. In APA Handbook of Forensic Psychology. Vol 2. Criminal Investigation, Adjudication and Sentencing Outcomes. Washington DC; 2015. pp. 245-270.

19. Petersen HD, Jacobsen, P. Psychical and physical symptoms after torture. A prospective controlled study. Forensic Sci Int. 1985;29:179-89.

20. Biurrun JM. Las relaciones de tortura. Iralka editorial. San Sebastian; 1994.

21. Meana, JJ, Morentin B, Callado LF, Idoyaga MI. Prevalence of sexual torture in political dissidents. The Lancet 1995; 345:1307.

22. Arzuaga J. Oso Latza izan da. Tortura Euskal Herrian. [It has been so tough. Torture in the Basque Country] Euskal Memoria, Donostia-San Sebastian; 2012.

23. Torturaren Aurkako Taldea. Annual Reports (2000-2014). Available from: www.stoptortura. org

24. Basque Government Presidency. Torture: a scientific approach (2000-2008). Vitoria-Gasteiz; 2009.

25. Morentin B, Callado LF, Idoyaga MI. A followup study of allegations of ill-treatment/torture in incommunicado detainees in Spain: failure of international preventive mechanisms. Torture 2008;18:87-98.

26. Zander M. The Police and Criminal Evidence Act 1984. Sweet \& Maxwell; 2013.

27. Hess JE. Interviewing interrogation for law enforcement. Lexisnexis; 2010.

28. Physicians for Human Rights. Break them down. Systematic use of psychological torture by US forces. Washington: Physicians for Human Rights; 2005.

29. Busch J, Hansen SH, Hougen HP. Geographical distribution of torture: An epidemiological study of torture reported by asylum applicants examined at the Department of Forensic Medicine, University of Copenhagen. Torture 2015; 2: 12-21. 


\section{Appendix A}

Statements: Allegations of torture of particular pertinence to the situation in the Basque Country, Spain

\section{Case 1.}

"They tell you: "We have five days to make you talk. One or two, may be, but three is always enough. You will see... ». And the worst thing is that it was true...five, even three days is enough to break a detainee. They get you mad".

\section{Case 2.}

"On the way to Madrid she [a policewoman] told me: "You'll see when you get there. There are three phases. You all do the same. At first, you do not want to talk. In the second you're going to tell some lies, you're going to say things that are a lie. And at the end there is the phase in which you will tell the truth. You are going to get there»...”.

\section{Case 3.}

"There came a time when I did not think any more, and I was not aware of anything; moments of heavy burdens, madness, crazy ideas."

\section{Case 4.}

"There were moments that I didn't want to live through... I wanted to get out of there; they were the longest five days of my life. It seemed that they were never ending. There were times when you felt you were going to go crazy, at some point you were so tired that you had no reflexes, they spoke to me and I looked like a zombie, I could not coordinate." 